Gut, 1972, 13, 243-250

\title{
Aspects of duodeno-gastric reflux in man
}

\author{
K. G. WORMSLEY \\ From Maryfield Hospital, Dundee
}

SUMMARY Duodeno-gastric reflux has been studied in normal subjects and patients with duodenal and gastric ulceration during the responses to parenteral secretin and cholecystokinin-pancreozymin and to acidification of the small intestine. Reflux was absent or slight in normal subjects and most patients with duodenal ulcer but was appreciable in most patients with gastric ulcer. Duodeno-gastric regurgitation may occasionally resultin a misleading assessment of pancreatic exocrine secretory capacity.

Duodeno-gastric reflux was considered to represent a 'protective' mechanism in the early years of the present century (Spencer, Meyer, Rehfuss, and Hawk, 1916) but was then largely ignored until the recent converse suggestion that duodenal contents, particularly bile salts and pancreatic enzymes, were involved in the pathogenesis of gastric ulceration $(\mathrm{Du}$ Plessis, 1965; Capper, 1967) and of atrophic gastritis (Siurala and Tawast, 1956).

In view of the lack of precise information regarding the incidence and significance of regurgitation of duodenal contents into the stomach in health and disease, the present study has attempted to quantitate duodeno-gastric reflux under conditions of endogenous and exogenous stimulation of secretion into the duodenum.

\section{Methods}

The subjects of the present investigation, whose informed consent had been obtained, comprised 39 healthy controls $(\mathrm{N}) ; 35$ patients with duodenal ulcer (DU), of whom 21 were restudied after truncal vagotomy and pyloroplasty; 15 patients with ulceration of the lesser curve of the stomach above the angulus (GU), eight of whom were restudied after Billroth I gastrectomy; and three patients with chronic pancreatitis (CP). Only subjects who tolerated intubation without feeling nauseated were included in the study.

Techniques of intubation of the stomach and duodenum and analysis of the duodenal and gastric aspirates and secretory stimulation have been described in detail previously (Wormsley, 1969, 1970; Goldberg and Wormsley, 1970). After a 12-hour

Received for publication 20 January 1972. overnight fast, each subject was intubated with a modified Dreiling tube, so that the tip lay just proximal to the ligament of Treitz and with a Ryle's tube sited in the antrum. The position of the tubes was checked radiologically during and after the tests. The subjects sat upright during the studies. Duodenal and gastric aspirates were collected in 10-minute batches. Acid concentration was measured by titra-

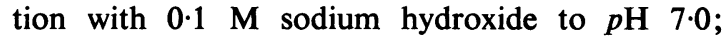
bicarbonate concentration by the addition of $2 \mathrm{ml}$ $0 \cdot 1 \mathrm{M}$ hydrochloric acid to $1 \mathrm{ml}$ samples, boiling and backtitrating to $p \mathrm{H} \mathrm{7.0;} \mathrm{bile} \mathrm{pigment} \mathrm{as} \mathrm{icteric} \mathrm{index}$ (after immediate alkalinization, if necessary, in gastric aspirate); trypsin as proteolytic activity and titrimetrically, using p-tosyl arginine methyl ester as substrate; and polyethylene glycol 4000 (PEG) by the method of Hyden (1955).

\section{RECOVERY OF COMPONENTS OF DUODENAL}

JUICE

To test recovery of bile pigment, aliquots of duodenal aspirate from normal subjects were treated with an excess of acid-containing gastric juice, so that the resultant mixture had a $p H$ of $1 \cdot 5$. The mixture was sampled at 15 -minute intervals for three hours. Samples were cleared with $0 \cdot 1 \mathrm{M}$ sodium hydroxide and the icteric index was compared with the appropriately diluted original control specimens of duodenal aspirate.

Recovery of trypsin was not reexamined, since trypsin had previously been shown to be fairly rapidly inactivated by the acid plus pepsin of gastric juice (Heizer, Cleaveland, and Iber, 1965; Khayat and Christophe, 1969).

STIMULANT SCHEDULES

Duodeno-gastric reflux was studied in subjects who 
were undergoing routine tests of pancreatic function with stimulant schedules comprising: (1) 23 subjects (13 $\mathrm{N}$; $9 \mathrm{DU} ; 1 \mathrm{GU})$ received 0.25 clinical units (CU)/ $\mathrm{kg}$ body weight each hour of secretin for 50 minutes; (2) 33 subjects (11 N; $16 \mathrm{DU}$; $6 \mathrm{GU}$ ) received $2.0 \mathrm{CU} / \mathrm{kg}$-hour secretin for 50 minutes. The first 10 subjects ( $3 \mathrm{~N}$; $5 \mathrm{DU} ; 2 \mathrm{GU}$ ) who were tested received an infusion of $0.15 \mathrm{M}$ sodium chloride ( $75 \mathrm{ml} /$ hour), containing PEG, into the first part of the duodenum; (3) 49 subjects ( $29 \mathrm{~N} ; 12 \mathrm{DU} ; 8$ GU) received $0.25 \mathrm{CU} / \mathrm{kg}$-hour secretin plus 4.0 Ivy units (IU)/kg-hour cholecystokinin-pancreozymin (CCK-PZ) for 50 minutes.

(All hormones were obtained from the GIH Laboratory, Karolinska Institute, Stockholm, Sweden.)

Reflux into the stomach was also studied in subjects receiving acid infusions into the small intestine: (4) $50 \mathrm{mM}$ hydrochloric acid (+ $100 \mathrm{mM}$ sodium chloride + PEG (2.5 g/l)) was infused into the first part of the duodenum in 36 subjects $(10 \mathrm{~N} ; 13 \mathrm{DU}$; $10 \mathrm{GU} ; 3 \mathrm{CP}$ ) at a rate of $220 \mathrm{ml}$ in 30 minutes; (5) $50 \mathrm{mM} \mathrm{HCl}$ (as above, schedule 4) was infused into the jejunum in 31 subjects $(10 \mathrm{~N} ; 18 \mathrm{DU} ; 3 \mathrm{GU})$ at a rate of $440 \mathrm{ml} /$ hour for 50 minutes.

\section{CALCULATIONS}

When an indicator (PEG) was infused into the duodenum (schedules 2 and 4) or into the jejunum (schedule 5), recovery of the indicator from the stomach was measured. The degree of reflux has been expressed as the proportion of the infused load of PEG recovered from the stomach.

During stimulation with hormones when no marker was used and during jejunal acidification, duodeno-gastric reflux was assessed from recovery of bile pigment, trypsin, and bicarbonate in the gastric aspirate. The amount of each component in the gastric aspirate was expressed as a proportion (percentage) of the total aspirated from both stomach and duodenum. Recovery of bicarbonate and, to a lesser extent, of trypsin would therefore be underestimated if reflux occurred into an acidcontaining gastric lumen.

\section{Results}

\section{SITE OF TUBES}

No shift in the radiological position of the tubes was noted during the period of the test in any individual.

\section{RECOVERY OF BILE PIGMENT}

Bile pigment can be measured in acid gastric contents if the turbidity is cleared by the addition of sodium hydroxide. Immediately after clearing, the values of bile pigment concentration range from 160 to $120 \%$ of control and decrease to constant, control levels during 15 to 30 minutes. Providing $\mathbf{3 0}$ minutes were allowed to elapse between clearing and colorimetric estimation, recovery of bile pigment was complete for at least three hours after mixing gastric and duodenal juice.

INTERRELATIONSHIPS OF BILE PIGMENT,

TRYPSIN, AND BICARBONATE

When the gastric aspirate was alkaline, reflux of the three components of duodenal juice ran parallel during each collection period, although the overall relative proportions of the bicarbonate, trypsin, and bile pigment recovered from the stomach depended

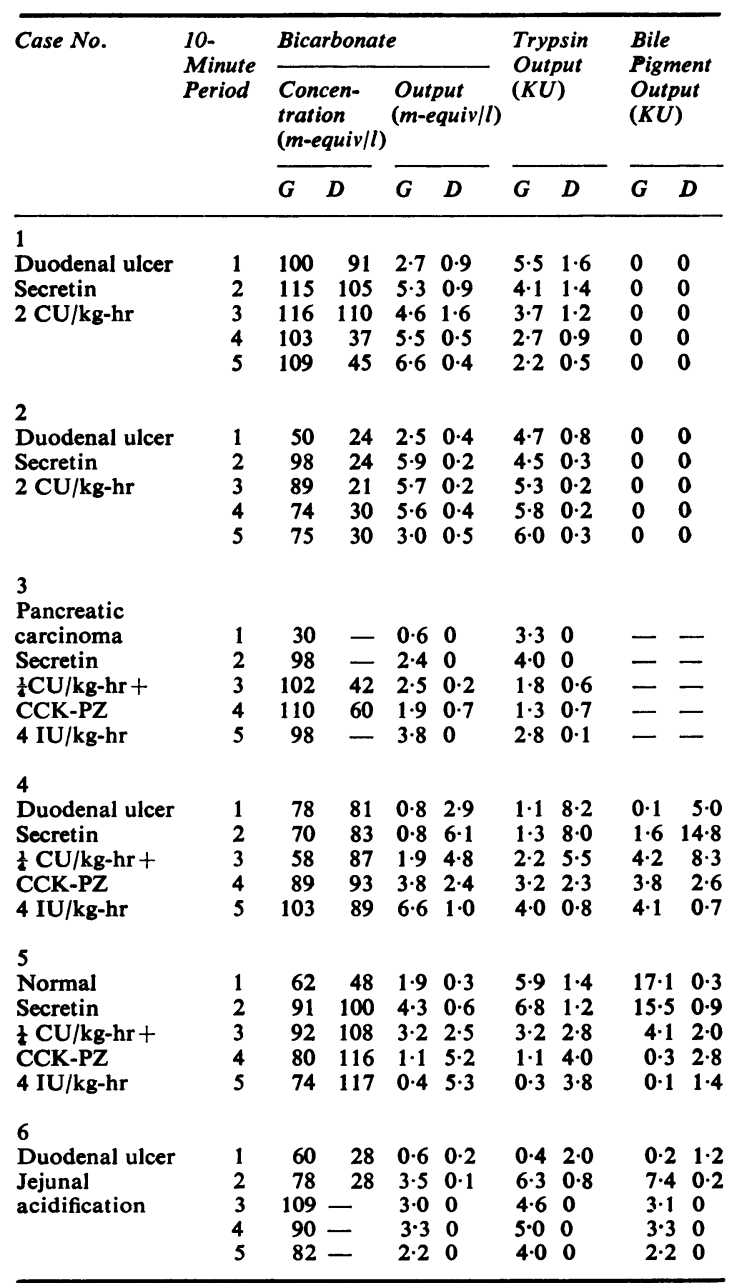

Table I Representative patterns of severe reflux in six subjects

$\mathbf{G}=$ aspirate from stomach

$\mathrm{D}=$ aspirate from duodenum

Note the greater recovery of pancreatic juice and bile from stomach than duodenum in all cases. 
on the time course of regurgitation. Maximal discharge of bile pigment occurs immediately after the onset of contraction of the gall bladder, so that reflux during the early phases of a study may lead to disproportionately large losses of bile into the stomach (Table I, case 5). Conversely, reflux of bicarbonate and trypsin is relatively greater than reflux of bile pigment when regurgitation only occurs later during the course of stimulation (Table I, case 4). Reflux of bicarbonate and trypsin, without bile, is also found when pancreatic juice is secreted without discharge of bile into the duodenum during infusion of secretin or during duodenal acidification (Table I, cases 1 and 2).

The concentration of bicarbonate in the duodenal aspirate was usually greater than in gastric aspirate, but in 10 subjects the concentration of bicarbonate in the gastric aspirate was appreciably greater (range 6 to 74 m-equiv/l) than in duodenal aspirate. In three subjects, the concentrations and outputs of bicarbonate recovered from the duodenum were so abnormally low as to suggest pancreatic exocrine insufficiency, while the concentrations and outputs of bicarbonate aspirated from the stomach were quite normal (Table I, case 2). The concentration of trypsin was greater in gastric than duodenal aspirate in six subjects, while bile pigment concentration was greater in gastric than duodenal aspirate in seven subjects.
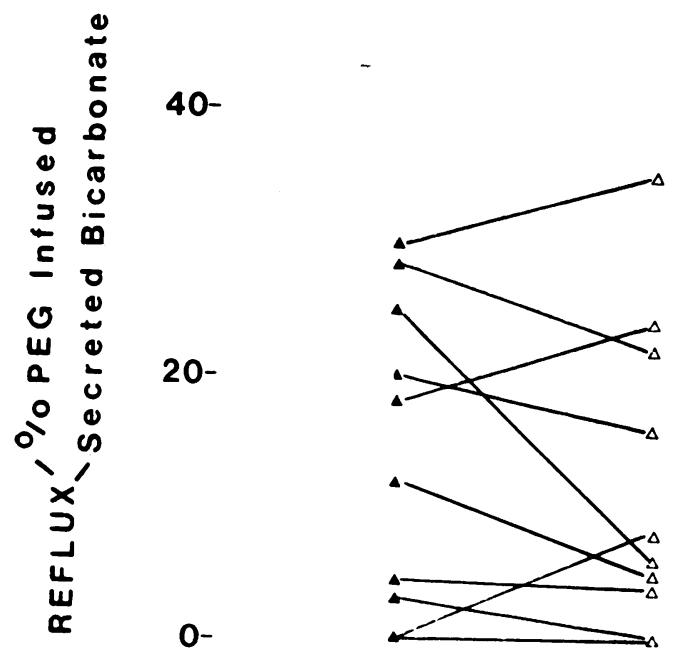

\section{PE G}

$\mathrm{HCO}_{3}$

Fig. 1 Reflux of PEG and bicarbonate during response to secretin (2.0 CU/kg-hour).

Each pair of points represents results from one subject.

The ordinate indicates the proportion $(\%)$ of infused PEG and secreted bicarbonate, respectively, which regurgitated.
REFLUX DURING INTRAVENOUS INFUSION OF HORMONES

There was little or no reflux of duodenal contents into the stomach during the response to the hormonal stimulant schedules in the majority of normal and duodenal ulcer subjects (Table II; Fig. 1). The

\begin{tabular}{|c|c|c|c|c|c|c|c|c|c|c|c|}
\hline \multicolumn{2}{|c|}{ Hormone } & \multicolumn{9}{|c|}{ Subjects with Reflux } & \multirow{2}{*}{$\begin{array}{l}\text { Subject } \\
\text { without } \\
\text { Reflux }\end{array}$} \\
\hline & & 1 & 2 & 3 & 4 & 5 & 6 & 7 & 8 & 9 & \\
\hline \multicolumn{12}{|c|}{0.25 CU/kg-hr Secretin } \\
\hline & $\mathrm{HCO}_{3}$ & 22 & 6 & 26 & 22 & 4 & 3 & & & & \\
\hline \multirow[t]{2}{*}{$N$} & & $\begin{array}{r}38 \\
0\end{array}$ & $\begin{array}{r}10 \\
0\end{array}$ & $\begin{array}{r}24 \\
0\end{array}$ & $\begin{array}{r}19 \\
3\end{array}$ & $\begin{array}{l}6 \\
0\end{array}$ & $\begin{array}{l}1 \\
0\end{array}$ & & & & 7 \\
\hline & $\mathrm{HCO}$, & 10 & 23 & 26 & 27 & 13 & & & & & \\
\hline \multirow[t]{2}{*}{$D U$} & & $\begin{array}{r}16 \\
0\end{array}$ & $\begin{array}{r}22 \\
0\end{array}$ & $\begin{array}{l}19 \\
21\end{array}$ & $\begin{array}{l}30 \\
40\end{array}$ & $\begin{array}{r}11 \\
0\end{array}$ & & & & & 4 \\
\hline & $\mathrm{HCO}_{3}$ & 16 & & & & & & & & & \\
\hline$G U$ & $\begin{array}{l}\text { TR } \\
\text { BP }\end{array}$ & $\begin{array}{l}23 \\
26\end{array}$ & & & & & & & & & \\
\hline \multicolumn{12}{|c|}{$2.0 \mathrm{CU} / \mathrm{kg}-\mathrm{hr}$ Secretin } \\
\hline & $\mathrm{HCO}_{3}$ & 4 & 8 & 66 & 2 & 10 & & & & & \\
\hline \multirow[t]{2}{*}{$N$} & $\begin{array}{l}\text { TR } \\
\text { BP }\end{array}$ & $\begin{array}{l}6 \\
0\end{array}$ & $\begin{array}{l}8 \\
0\end{array}$ & $\begin{array}{l}54 \\
71\end{array}$ & $\begin{array}{l}4 \\
0\end{array}$ & $\begin{array}{l}8 \\
0\end{array}$ & & & & & 6 \\
\hline & $\mathrm{HCO}_{3}$ & 48 & 1 & 85 & 2 & 6 & 5 & 2 & 94 & 4 & \\
\hline \multirow[t]{3}{*}{$D U$} & TR & 29 & 1 & 77 & 3 & 5 & 6 & 1 & 94 & 6 & 7 \\
\hline & BP & $\mathbf{0}$ & $\mathbf{0}$ & $\mathbf{0}$ & $\mathbf{0}$ & $\mathbf{0}$ & $\mathbf{0}$ & $\mathbf{0}$ & $\mathbf{0}$ & 0 & \\
\hline & $\mathrm{HCO}_{2}$ & 55 & 20 & 23 & 14 & 36 & 7 & & & & \\
\hline \multirow[t]{2}{*}{$G U$} & TR & 48 & 26 & 23 & 18 & 30 & 8 & & & & \\
\hline & BP & 32 & 18 & 12 & 12 & 41 & 4 & & & & \\
\hline \multicolumn{12}{|c|}{$0.25 C U / K g-h r$ Secretin plus $4.0 \mathrm{IU} / \mathrm{Kg}$-hr CCK-PZ } \\
\hline \multirow{4}{*}{$N$} & $\mathrm{HCO}_{3}$ & 4 & 2 & 1 & 2 & 10 & 5 & 12 & 2 & 43 & \\
\hline & TR & 8 & 4 & 1 & 1 & 8 & 7 & 14 & 3 & 57 & 20 \\
\hline & BP & 6 & 4 & 1 & 5 & 3 & 7 & 18 & 3 & 84 & \\
\hline & $\mathrm{HCO}_{8}$ & 49 & 28 & 43 & 8 & 4 & & & & & \\
\hline \multirow[t]{3}{*}{$D U$} & TR & 49 & 30 & 28 & 13 & 6 & & & & & 7 \\
\hline & BP & 22 & 47 & 30 & 7 & 4 & & & & & \\
\hline & $\mathrm{HCO}_{3}$ & 23 & 52 & 9 & 53 & 45 & 57 & & & & \\
\hline \multirow[t]{2}{*}{$\boldsymbol{G U}$} & TR & 21 & 55 & 8 & 58 & 47 & 52 & & & & 2 \\
\hline & BP & 26 & 57 & 4 & 62 & 42 & 53 & & & & \\
\hline
\end{tabular}

Table II Reflux during response to hormones

Each set of three numbers in the vertical columns represents the proportion (\%) of the total secreted bicarbonate $\left(\mathrm{HCO}_{3}\right)$, trypsin (TR) and bile pigment (BP) regurgitated into the stomach in individual subjects.

$\mathbf{N}=$ normal subjects; $\mathbf{D U}=$ duodenal ulcer; $\mathbf{G U}=$ gastric ulcer. Note that reflux of bicarbonate and trypsin generally similar order of magnitude. Reflux of bile pigment less than former during secretin infusions due to inhibition of gall bladder emptying by secretin.

tendency to reflux was not greater with the higher compared with the lower dose rate of secretin (Fig. 2), although a greater proportion of dudenal contents was regurgitated during the infusion of the high dose of secretin in some individuals (Table II). The time course of reflux, when present, varied from individual to individual (Fig. 3), but most of the patients with gastric ulceration showed reflux throughout the response to hormonal stimulation.

The degree of reflux in response to hormones did not change significantly after vagotomy and pyloroplasty (Table III). The effect of Billroth I gastrectomy on reflux was variable (Table IV). 
60-

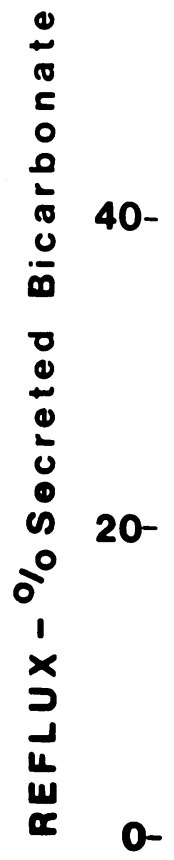

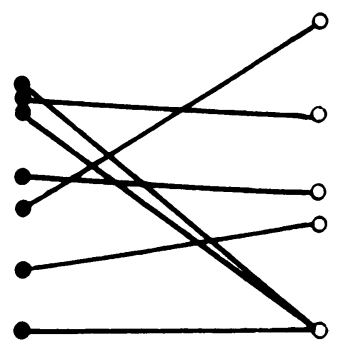

0.25

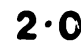

$2 \cdot 0$

Fig. 2 Reflux of bicarbonate during response to secretin (0.25 and 2.0 CU/kg-hour).

Each pair of points represents results from one subject.

\begin{tabular}{|c|c|c|}
\hline \multirow[t]{3}{*}{ Time Related to Operation } & Subjects with Reflux & \multirow{3}{*}{$\begin{array}{l}\text { Subjects } \\
\text { without } \\
\text { Reflux }\end{array}$} \\
\hline & Case No. & \\
\hline & $\begin{array}{lllll}1 & 2 & 3 & 4 & 5\end{array}$ & \\
\hline
\end{tabular}

2.0 CU/kg-hr Secretin

$\begin{array}{llrrrrrr}2 \cdot 0 \mathrm{CU} / \mathrm{kg}-\mathrm{hr} \text { Secretin } & & & & \\ & \text { HCO } & & 5 & 5 & 2 & 94 & \\ \text { Before } & \text { TR } & 3 & 5 & 6 & 1 & 94 & \\ & \text { BP } & 0 & 0 & 0 & 0 & 0 & 4 \\ & \text { HCO } & 3 & 0 & 10 & 1 & 54 & 4 \\ \text { After } & \text { TR } & 12 & 0 & 12 & 1 & 49 & \\ & \text { BP } & 0 & 0 & 17 & 0 & 27 & \end{array}$

0.25 CU/kg-hr Secretin + 4.0 IU/kg-hr CCK-PZ

$\begin{array}{rlrrrrrr} & \mathrm{HCO}_{3} & 0 & 43 & 0 & 4 & 8 & \\ \text { Before } & \text { TR } & 0 & 28 & 0 & 6 & 13 & \\ & \text { BP } & 0 & 30 & 0 & 4 & 7 & \\ & \text { HCO } & 2 & 5 & 73 & 12 & 20 & 2 \\ \text { After } & \text { TR } & 2 & 5 & 71 & 6 & 24 & \\ & \text { BP } & 4 & 7 & 63 & 9 & 29 & \end{array}$

Table III Reflux before and after vagotomy and pyloroplasty

Each set of six numbers in each vertical column represents the proportion $(\%)$ of the total secreted bicarbonate $\left(\mathrm{HCO}_{3}\right)$, trypsin (TR), and bile pigment (BP) regurgitated into the stomach before and after vagotomy and pyloroplasty.

Note similar magnitude of reflux of bicarbonate and trypsin.

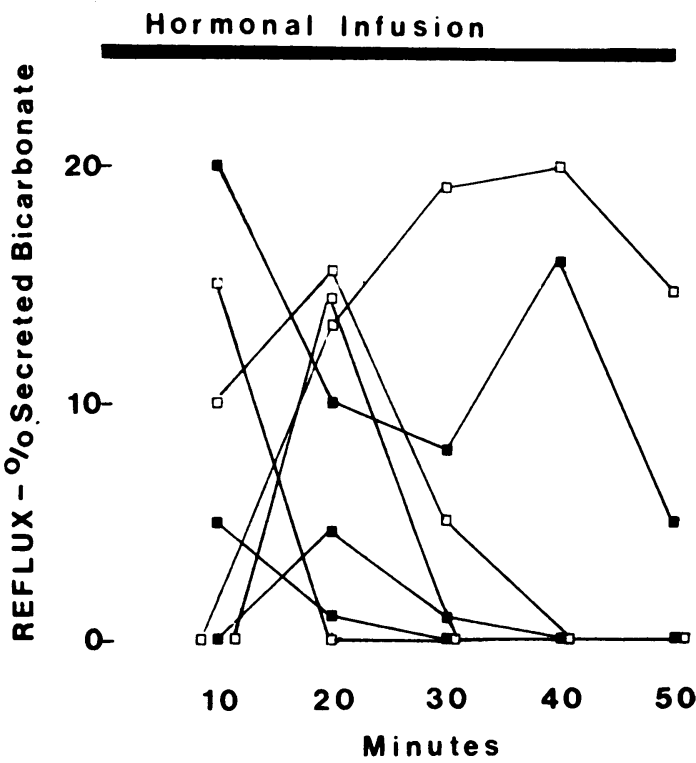

Fig. 3 Time course of reflux of bicarbonate during response to intravenous hormones.

The seven representative curves show the patterns of reflux encountered.

Open squares $=2.0 \mathrm{CU} / \mathrm{kg}$-hour secretin; closed squares $=0.25 \mathrm{CU} / \mathrm{kg}$-hour secretin plus $4.0 \mathrm{IU} / \mathrm{kg}$-hour CKK-PZ.

\begin{tabular}{|c|c|c|c|c|c|c|c|c|c|}
\hline \multirow{2}{*}{\multicolumn{2}{|c|}{$\begin{array}{l}\text { Time Related to } \\
\text { Operation }\end{array}$}} & \multicolumn{8}{|c|}{ Case No. } \\
\hline & & 1 & 2 & 3 & 4 & 5 & 6 & 7 & 8 \\
\hline \multirow{3}{*}{ Bafore } & $\mathrm{HCO}_{3}$ & 0 & 23 & 52 & 9 & 0 & 53 & 45 & 57 \\
\hline & TR & $\mathbf{0}$ & 21 & 55 & 8 & 0 & 58 & 47 & 52 \\
\hline & & 0 & 26 & 57 & 4 & 0 & 62 & 42 & 5 \\
\hline \multirow{3}{*}{ After } & $\mathrm{HCO}_{3}$ & 0 & 55 & 46 & 26 & 58 & 49 & 0 & 58 \\
\hline & TR & 0 & 48 & 43 & 31 & 55 & 52 & 0 & 55 \\
\hline & $\mathbf{B P}$ & 0 & 48 & 49 & 40 & 64 & 56 & 0 & 58 \\
\hline
\end{tabular}

Table IV Reflux before and after Billroth I gastrectomy

Patients with GU received $0.25 \mathrm{CU} / \mathrm{kg}-\mathrm{hr}$ secretin $+4.0 \mathrm{IU} / \mathrm{kg}-\mathrm{hr}$ CCK-PZ.

Significance of numbers and symbols as in Table III.

Note similar magnitude of reflux of bicarbonate, trypsin, and bile pigment

REFLUX DURING DUODENAL ACIDIFICATION No reflux, or regurgitation of $10 \%$ or less of PEG, was found in all except one normal subject and in half of the patients with duodenal ulcer. All the patients with gastric ulcer regurgitated PEG into the stomach, often to a marked degree. Marked regurgitation also characterized the response to duodenal acidification of patients with chronic pancreatitis (Figs. 4 and 5).

The five patients with duodenal ulcer who 


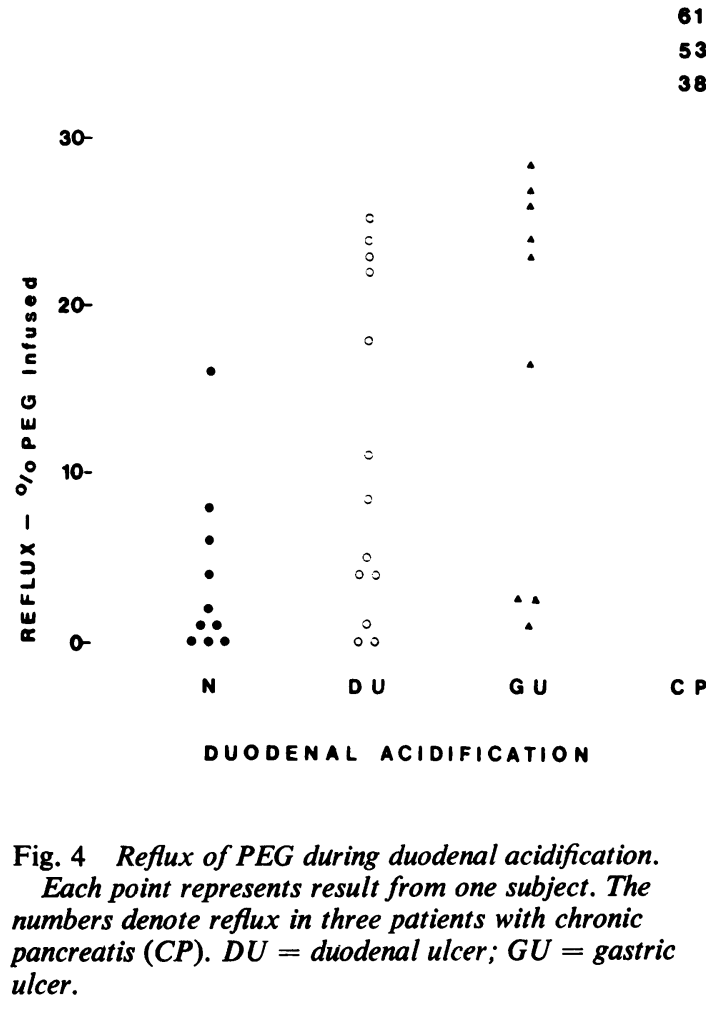

D U regurgitated more than $15 \%$ of their load of PEG included two with ulcer at the pylorus. Three patients with duodenal plus gastric ulcer regurgitated 0,2 , and $5 \%$ of PEG into the stomach, respectively.

There was no significant change in the degree of reflux of PEG after vagotomy and pyloroplasty (Table V).

\section{REFLUX DURING JEJUNAL ACIDIFICATION (TABLE VI)}

Marked (more than 20\%) reflux during jejunal acidification occurred in subjects who also showed severe reflux during infusion of hormones. In three individuals PEG was regurgitated from the upper jejunum into the stomach $(19,7$, and $4 \%$ of the PEG load, respectively).

When reflux occurred during the response to jejunal acidification, the pattern was variable (Fig. 6). Regurgitation was often maximal, or occurred exclusively, during the first 10 minutes of the study. However, just over half of the subjects only developed duodeno-gastric reflux after stopping the jejunal infusion of acid, or showed marked increase in the degree of reflux at this time (Fig. 6).

\section{REPRODUCIBILITY}

Subjects tended to show similar orders of reflux in response to duplicate tests (Table VII).

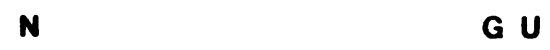

Fig. 5 Time course of reflux of PEG during duodenal acidification.

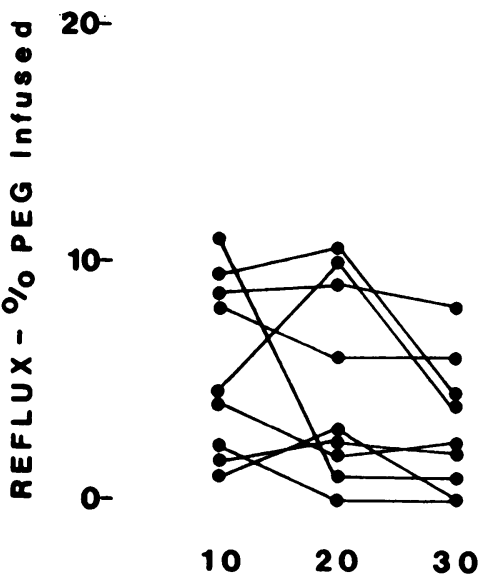

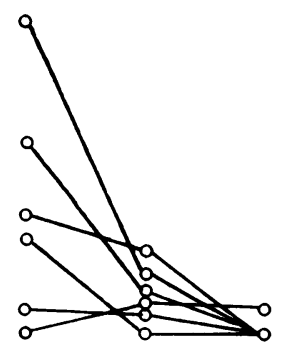

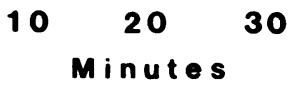

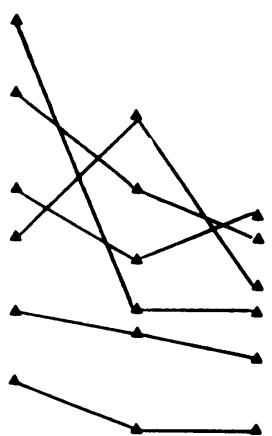

$1020 \quad 30$

DUODENAL ACIDIFICATION

Each series of three points depicts the pattern of reflux in representative normal subjects $(N)$ and patients with duodenal ulcer $(D U)$ or gastric ulcer $(G U)$. (For the sake of clarity, not all the data shown in Fig. 4 are reproduced in Figure 5.) 


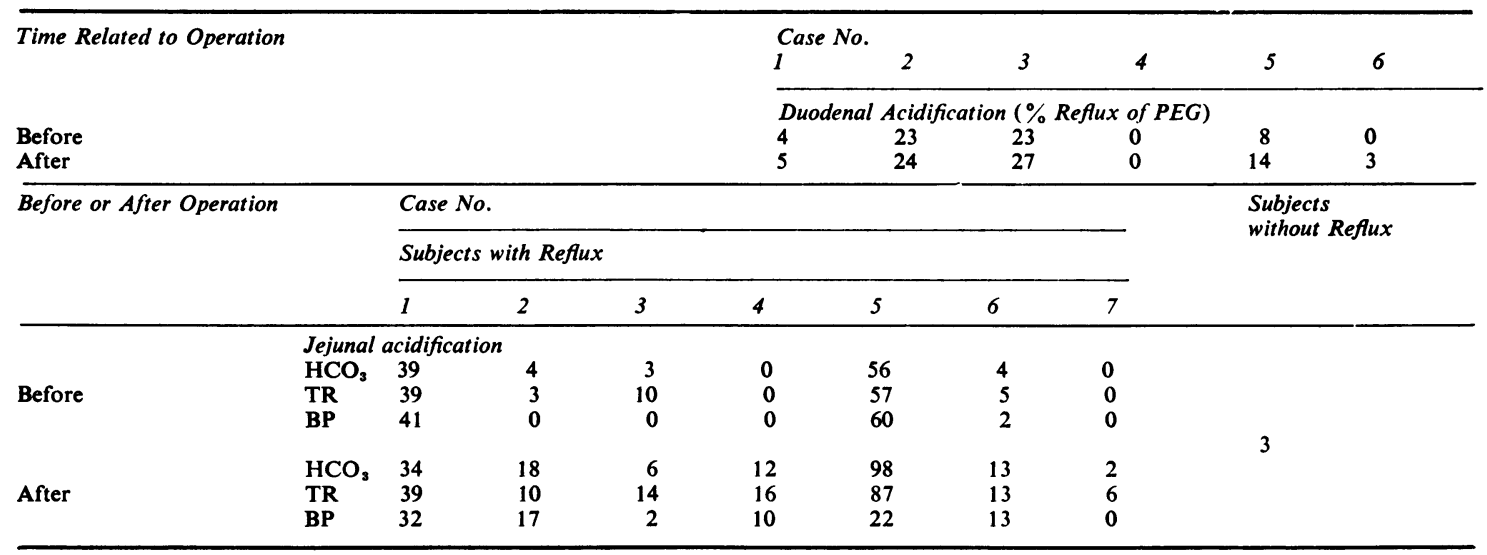

Table V Effect of vagotomy and pyloroplasty on reflux

Significance of numbers and symbols as in Table III. Pairs of values of PEG denote reflux of PEG during duodenal acidification.

\begin{tabular}{|c|c|c|c|c|c|c|c|c|c|c|c|}
\hline & & \multicolumn{9}{|c|}{ Subjects with Reflux } & \multirow{3}{*}{$\begin{array}{l}\text { Subjects } \\
\text { without } \\
\text { Reflux }\end{array}$} \\
\hline & & \multicolumn{9}{|c|}{ Case No. } & \\
\hline & & 1 & 2 & 3 & 4 & 5 & 6 & 7 & 8 & 9 & \\
\hline$N$ & $\begin{array}{l}\mathrm{HCO}_{3} \\
\text { TR } \\
\text { BP }\end{array}$ & $\begin{array}{l}4 \\
4 \\
0\end{array}$ & $\begin{array}{l}4 \\
6 \\
0\end{array}$ & $\begin{array}{l}5 \\
3 \\
3\end{array}$ & $\begin{array}{l}2 \\
3 \\
2\end{array}$ & $\begin{array}{l}7 \\
8 \\
5\end{array}$ & & & & & 5 \\
\hline$D U$ & $\begin{array}{l}\mathrm{HCO}_{3} \\
\text { TR } \\
\text { BP }\end{array}$ & $\begin{array}{l}13 \\
16 \\
16\end{array}$ & $\begin{array}{l}4 \\
4 \\
0\end{array}$ & $\begin{array}{l}10 \\
12 \\
15\end{array}$ & $\begin{array}{l}1 \\
5 \\
0\end{array}$ & $\begin{array}{r}8 \\
6 \\
11\end{array}$ & $\begin{array}{l}39 \\
39 \\
41\end{array}$ & $\begin{array}{l}2 \\
3 \\
0\end{array}$ & $\begin{array}{r}3 \\
10 \\
0\end{array}$ & $\begin{array}{l}56 \\
57 \\
53\end{array}$ & 9 \\
\hline$G U$ & $\begin{array}{l}\mathrm{HCO}_{3} \\
\text { TR } \\
\text { BP }\end{array}$ & $\begin{array}{r}8 \\
12 \\
11\end{array}$ & $\begin{array}{l}4 \\
5 \\
2\end{array}$ & $\begin{array}{l}24 \\
20 \\
28\end{array}$ & & & & & & & \\
\hline
\end{tabular}

Table VI Reflux during jejunal acidification

Significance of numbers and symbols as in Table II.

Note similar magnitude of reflux of all three components of duodenal contents.

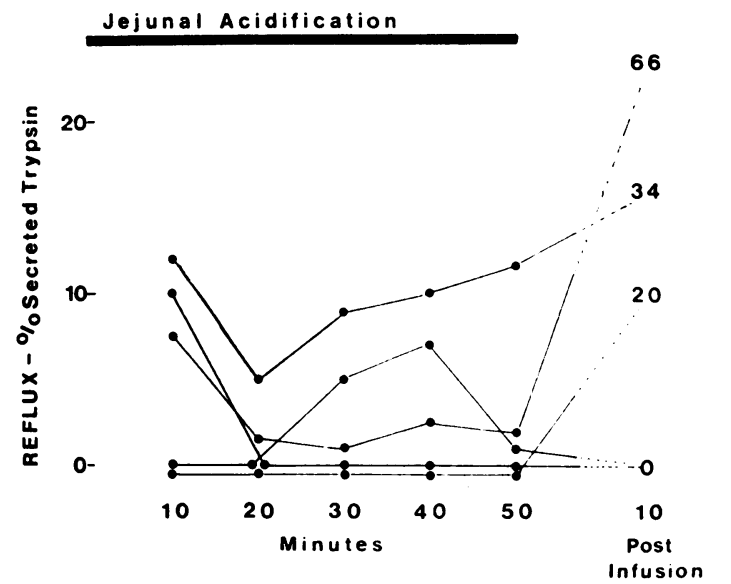

Fig. 6 Time course of reflux during jejunal acidification

Each set of six points depicts a representative pattern of reflux of trypsin during the response to jejunal acidification. The numbers in the right-hand vertical column show the types of 'rebound' reflux encountered after stopping acidification.

\begin{tabular}{|c|c|c|c|c|c|c|c|c|c|c|c|c|}
\hline & \multicolumn{12}{|c|}{ Case No. } \\
\hline & \multicolumn{2}{|l|}{1} & \multicolumn{2}{|l|}{2} & \multicolumn{2}{|l|}{3} & \multicolumn{2}{|l|}{4} & \multicolumn{2}{|l|}{5} & \multicolumn{2}{|l|}{6} \\
\hline & $A$ & $\boldsymbol{B}$ & $A$ & $B$ & $A$ & $B$ & $A$ & $B$ & $A$ & $B$ & $A$ & $B$ \\
\hline $\begin{array}{c}0.25 \mathrm{CU} / \mathrm{Kg}-\mathrm{hr} \\
\mathrm{HCO}_{3} \\
\text { TR } \\
\text { BP }\end{array}$ & $\begin{array}{c}S e c r \\
10 \\
16 \\
0\end{array}$ & $\begin{array}{r}\text { etin } \\
0 \\
0 \\
0\end{array}$ & $\begin{array}{l}4 \\
6 \\
0\end{array}$ & $\begin{array}{l}0 \\
0 \\
0\end{array}$ & $\begin{array}{l}3 \\
1 \\
0\end{array}$ & $\begin{array}{l}0 \\
0 \\
0\end{array}$ & $\begin{array}{r}26 \\
19 \\
0\end{array}$ & $\begin{array}{l}0 \\
0 \\
0\end{array}$ & $\begin{array}{l}0 \\
0 \\
0\end{array}$ & $\begin{array}{l}0 \\
0 \\
0\end{array}$ & $\begin{array}{l}\mathbf{0} \\
\mathbf{0} \\
\mathbf{0}\end{array}$ & $\begin{array}{l}0 \\
0 \\
0\end{array}$ \\
\hline $\begin{array}{c}2 \cdot 0 \mathrm{CU} / \mathrm{Kg}-\mathrm{hr} \\
\mathrm{HCO}_{3} \\
\text { TR } \\
\text { BP }\end{array}$ & $\begin{array}{c}\text { iecre } \\
2 \\
3 \\
0\end{array}$ & $\begin{array}{r}\text { in } \\
8 \\
12 \\
0\end{array}$ & $\begin{array}{r}19 \\
18 \\
0\end{array}$ & $\begin{array}{l}54 \\
49 \\
27\end{array}$ & $\begin{array}{l}12 \\
24 \\
16\end{array}$ & $\begin{array}{l}0 \\
0 \\
0\end{array}$ & $\begin{array}{l}0 \\
0 \\
0\end{array}$ & $\begin{array}{l}4 \\
7 \\
0\end{array}$ & $\begin{array}{l}0 \\
0 \\
0\end{array}$ & $\begin{array}{l}0 \\
0 \\
0\end{array}$ & & \\
\hline $\begin{array}{c}0.25 \mathrm{CU} / \mathrm{Kg}-\mathrm{hr} \\
\mathrm{HCO}_{3} \\
\text { TR } \\
\text { BP }\end{array}$ & $\begin{array}{c}S e c \\
43 \\
28 \\
30\end{array}$ & $\begin{array}{r}\text { etin } \\
8 \\
13 \\
7\end{array}$ & $\begin{array}{r}+4 \\
0 \\
0 \\
0\end{array}$ & $\begin{array}{r}0 I L \\
4 \\
5 \\
2\end{array}$ & $\begin{array}{r}\mid K g \\
0 \\
0 \\
0\end{array}$ & $\begin{aligned} \operatorname{hr} C \\
0 \\
0 \\
0\end{aligned}$ & $\begin{array}{r}C K \\
0 \\
0 \\
0\end{array}$ & $\begin{array}{l}P Z \\
0 \\
0 \\
0\end{array}$ & & & & \\
\hline $\begin{array}{c}\text { Duodenal Acid } \\
\text { PEG }\end{array}$ & 0 & 6 & 23 & 26 & 4 & 0 & 0 & 0 & 0 & 0 & & \\
\hline $\begin{array}{c}\text { Jejunal Acid } \\
\mathrm{HCO}_{3} \\
\text { TR } \\
\text { BP }\end{array}$ & $\begin{array}{l}0 \\
0 \\
0\end{array}$ & $\begin{array}{l}2 \\
3 \\
0\end{array}$ & $\begin{array}{r}8 \\
6 \\
11\end{array}$ & $\begin{array}{l}21 \\
15 \\
27\end{array}$ & $\begin{array}{l}0 \\
0 \\
0\end{array}$ & $\begin{array}{l}0 \\
0 \\
0\end{array}$ & $\begin{array}{l}0 \\
0 \\
0\end{array}$ & $\begin{array}{l}0 \\
0 \\
0\end{array}$ & & & & \\
\hline
\end{tabular}

Table VII Reproducibility of reflux

Significance of numbers and symbols as in Table II. $A$ and $B$ at the top of each vertical column represent results of the first and second of the duplicate tests in each individual, respectively.

\section{Discussion}

About 50 years ago, regurgitation of duodenal contents into the stomach received considerable attention, particularly in connexion with the regulation of the intragastric content of acid (Boldyreff, 1914; Hicks and Visher, 1915; Spencer et al, 1916; Bolton and Goodhart, 1922; Elman, 1928; Olch and Elman, 1927; Olch, 1928; Wilhelmj, Neigus, and Hill, 1934). Regurgitation was considered so desirable that reflux was operatively induced in patients with peptic ulceration (Braithwaite, 1943). However, when the studies of MacLean and Griffiths (1928) and of Shay, Katz, and Schloss (1932) sug- 
gested that duodenal regurgitation was not a significant factor in reducing gastric acid content, interest in the phenomenon waned. Instead, duodenogastric regurgitation came to be regarded as a technical nuisance, since duodenal contents reduced the concentration of acid and destroyed pepsin (Berstad, 1971) during tests of gastric function, while reflux into the stomach during tests of pancreatic function resulted in the loss of bicarbonate (Lagerlöf, 1942; Sun, 1963) and the inactivation of regurgitated pancreatic enzymes (Heizer et al, 1965; Khayat and Christophe, 1969). Recently, interest in reflux from the duodenum has been rekindled by the suggestion that the regurgitated bile salts (Grant, Grossman, Wang, and Ivy, 1951 ; Davenport, 1968) and pancreatic enzymes (Lawson, 1964; Delaney, Cheng, Butler, and Ritchie, 1970; Wenger and Trowbridge, 1970) may induce gastric mucosal damage.

The present study has shown that reflux from the duodenum occurs when acid is introduced into the small intestine or when small intestinal hormones are infused parenterally. Duodeno-gastric reflux, following the introduction of acid into the duodenum, had been noted previously (Boldyreff, 1908; Hicks and Visher, 1915). The degree of regurgitation was related to the amount of acid introduced into the duodenum (Bolton and Goodhart, 1922), suggesting that regurgitation into the stomach was one of the mechanisms whereby the duodenum disposed of large acid loads. In the present study, regurgitation of duodenal contents into the stomach was also noted during jejunal acidification and even jejunal contents were occasionally aspirated from the stomach under these circumstances, suggesting active retropulsion. Reflux into the stomach of an alkaline solution infused into the jejunum had been noted previously (Gustke, Varma, and Soergel, 1970).

Reflux in response to parenteral secretin and CCKPZ tended to be most marked immediately after the onset of stimulation, but occasionally persisted throughout the infusion of hormones. From a technical point of view, loss of duodenal contents into the stomach was not significant in the majority of subjects and would have interfered with satisfactory evaluation of pancreatic exocrine function in only a few individuals. However, the occasional very severe degree of regurgitation during hormonal stimulation does emphasize that failure to aspirate gastric contents during tests of pancreatic function may result in gravely misleading assessment of pancreatic secretory capacity.

The pathophysiological significance of duodenogastric reflux is not clear. In comparing the different diagnostic groups, it has been assumed that if the double intubation has affected duodeno-gastric reflux, the change has been similar in each of the groups or has accentuated any underlying differences in pattern.

The distribution of values of reflux was not normal in any of the diagnostic groups. Regurgitation was not detectable, or slight, in the majority of normal subjects. The patients with duodenal ulcer did not appear to represent a functionally homogeneous group, since reflux was either minimal or was present to a significant degree, not only when the ulcer was situated at the pylorus, but also when sited within the duodenal bulb. Reflux was usually marked in patients with gastric ulceration. The findings of the present study resemble the results of investigations of fasting gastric contents (Watkinson, 1951; Borg, 1959; Du Plessis, 1965; George, Kennedy, and Connell, 1967) and of studies employing test meal techniques (Rhodes, Barnardo, Phillips, Rovelstad, and Hofmann, 1969; Black, Roberts, and Rhodes, 1971) or a radioopaque marker (Capper, Airth, and Kilby, 1966; Flint and Grech, 1970), which have shown that duodeno-gastric reflux is not significant in most normal subjects but is appreciable in many patients with gastric ulceration. Likewise, Ågren, Lagerlöf, and Berglund (1936) had observed that duodeno-gastric reflux after injection of secretin occurred particularly in patients with gastric achylia. However, even when a marked degree of duodenogastric reflux can be demonstrated, it is not permissible to infer that the regurgitation of duodena! contents is injurious or necessarily involved in the pathogenesis of gastric mucosal disease, both because the direct evidence is controversial (Cole, 1969; Davenport, 1970) and because the converse inference, of a 'protective reaction', has not yet been disproven.

The author gratefuly acknowledges receipt of a research grant from the Scottish Hospitals Endowment Research Trust.

\section{References}

Ågren, G., Lagerlöf, H., and Berglund, H. (1936). The secretin test of pancreatic function in the diagnosis of pancreatic disease. Acta med. scand., 90, 224-271.

Berstad, A. (1971). Inactivation of human gastric pepsin by duodenal juice. Scand. J. Gastroenterol., 6, 241-244.

Black, R. B., Roberts, G., and Rhodes, J. (1971). The effect of healing on bile reflux in gastric ulcer. Gut, 12, 552-558.

Boldyreff, W. (1908). Der Uebertritt des natürlichen Gemisches aus Pankreassaft Darmsaft und Galle in den Magen. Pflügers. Arch. ges. Physiol., 121, 13-53.

Boldyreff, W. (1914). The self-regulation of the acidity of the gastric contents and the real acidity of the gastric juice. Quart. $J$, ex. Physiol., 7, 1-12.

Bolton, C., and Goodhart, G. W. (1922). Duodenal regurgitation into the stomach during gastric digestion. Lancet, 1, 420-425.

Borg, I. (1959). Gastric flow and acidity before and after Billroth II and Billroth I for gastro-duodenal ulcer. Acta chir. scand., Suppl. 251.

Braithwaite, L. R. (1943). The role of bile in duodenal regurgitation. Brit. J. Surg., 31, 3-13.

Capper, W. M. (1967). Factors in the pathogenesis of gastric ulcer. Ann. roy. Coll. Surg. Engl., 40, 21-35. 
Capper, W. M., Airth, G. R., and Kilby, J. O. (1966). A test for pyloric regurgitation. Lancet, 2, 621-623.

Cole, G. J. (1969). The implications of bile in the stomach. Gut, 10, 864-867.

Davenport, H. W. (1968). Destruction of the gastric mucosal barrier by detergents and urea. Gastroenterology, 54, 175-181.

Davenport, H. W. (1970). Effect of lysolecithin, digitonin, and phospholipase A upon the dog's gastric mucosal barrier. Gastroenterology, 69, 505-509.

Delaney, J. P., Cheng, J. W. B., Butler, B. A., and Ritchie, W. P., Jr. (1970). Gastric ulcer and regurgitation gastritis. Gut, 11, 715719.

Du Plessis, D. J. (1965). Pathogenesis of gastric ulceration. Lancet, 1, 974-978.

Elman, R. (1928). Probable influence of pancreatic juice in the regulation of gastric a cidity. Arch Surg., 16, 1256-1265.

Flint, F. J., and Grech. P. (1970). Pyloric regurgitation and gastric ulcer. Gut, 11, 735-737.

George, J. D., Kennedy, T., and Connell, A. M. (1967). Gastric emptying a cid secretion, and duodenal regurgitation in gastric ulceration. (Abstr.) Gut, 8, 632.

Goldberg, D. M., and Wormsley, K. G. (1970). The interrelationships of pancreatic enzymes in human duodena! aspirate. Gut, 11, 859-866.

Grant, R., Grossman, M. I., Wang, K. J., and Ivy, A. C. (1951). The cytolytic action of some gastrointestinal secretions and enzymes on epithelial cells of the gastric and duodenal mucosa. J. cell. comp. Physiol., 37, 137-161.

Gustke, R. F., Varma, R. R., and Soergel, K. H. (1970). Gastric reflux during perfusion of the proximal small bowel. Gastroenterology, 59, 890-895.

Heizer, W. D., Cleaveland, C. R., and Iber, F. L. (1965). Gastric inactivation of pancreatic supplements. Johns Hopk. med. J., 116, 261-270.

Hicks, C. J., Jr., and Visher, J. W. (1915). Contributions to the physiology of the stomach. XXVII. The mechanism of regurgitation of duodenal contents into the stomach. Amer. $J$. Physiol., 39, 1-8.

Hyden, S. (1956). A turbidometric method for the determination of higher polyethylene glycols in biological materials. $K$. Lantbr Högsk. Annlr., 22, 139-145.

Khayat, M. H., and Christophe, J. (1969). In vitro inactivation of pancreatic enzymes in washings of the rat small intestine. Amer. J. Physiol., 217, 923-929.
Lagerlöf, H. O. (1942). Pancreatic function and pancreatic disease. Acta med. scand., Suppl. 128.

Lawson, H. H. (1964). Effect of duodenal contents on the gastric mucosa under experimental conditions. Lancet, 1, 469-472.

MacLean, H., and Griffiths, W. J. (1928). The factors influencing the concentration of hydrochloric acid during gastric digestion. J. Physiol. (Lond.), 65, 63-76.

Olch, I. Y. (1928). Duodenal regurgitation as a factor in neutralization of gastric acidity. Arch. Surg., 16, 125-138.

Olch, I. Y., and Elman, R. (1927). Regurgitation of duodenal contents as factor in neutralization of gastric acidity. Proc. Soc. exp. Biol. (N.Y.), 25, 184-186.

Rhodes, J., Barnardo, D. E., Phillips, S. F., Rovelstad, R. A., and Hofmann, A. F. (1969). Increased reflux of bile into the stomach in patients with gastric ulcer. Gasteroenterology, 57, 241-252.

Shay, H. Katz, A. B., and Schloss, E. M. (1932). Experimental studies in gastric physiology: evaluation of the role of duodenal regurgitation in the control of gastric acidity in man (Boldyreff theory). Arch. intern. Med., 50, 605-620.

Siurala, M., and Tawast, M. (1956). Duodenal regurgitation and the state of the gastric mucosa. Acta med. scand., 153, 451-458.

Spencer, W. H., Meyer, G. P. Rehfuss, M. E., and Hawk, P. B. (1916). Gastrointestinal studies. XII. Direct evidence of duodenal regurgitation and its influence upon the chemistry and function of the normal human stomach. Amer. J. Physiol., 39, 459-479.

Sun, D. C. H. (1963). Normal values for pancreozymin-secretin test. Gastroenterology, 44, 602-606.

Watkinson, G. (1951). A study of the changes in $\mathrm{pH}$ of gastric contents in peptic ulcer using the twenty-four hour test meal. Gastroenterology, 18, 377-390.

Wenger, J., and Trowbridge, C. G. (1970). Bile and trypsin in the stomach following a test meal. (Abstr.) Gastroenterology, $58,1010$.

Wilhelmj, C. M., Neigus, I., and Hill, F. C. (1934). A comparison of intragastric and duodenal factors lowering the acidity of gastric contents. Amer. J. Physiol., 107, 490-507.

Wormsley, K. G. (1969). Response to duodenal acidification in man. I. Electrolyte changes in the duodenal aspirate. Scand. J. Gastroenterol., 4, 717-726.

Wormsley, K. G. (1970). Response to duodenal a cidification in man. III. Comparison with the effects of secretin and pancreozymin. Scand. J. Gastroentercl., 5, 353-360. 